\title{
Identification of value: Reflections on the education of socialist core value system
}

\author{
Dai Caihong \\ Qiongtai Teachers College associate professor
}

\begin{abstract}
To improve college students' education of socialist core value system is effective, the value identity is important link. In education, we should give full play to the university thought politics theory class teaching as the main channel and the campus cultural environment influence character by environment effects, stimulates the student to the socialism core value system to guide college students in life, emotion, and actively practice the socialist core value system, to promote the college students with the socialist core value system value identity.
\end{abstract} Kentity

Keywords- the socialist core value system; education; value

\section{INTRODUCTION}

The socialist core value system is the inner spirit of the socialist system and the soul of life, the value target system of socialism in the dominant position .It is the common value orientation, the pursuit of the people of the whole country, provides guidelines for the development of harmonious culture and harmonious society, to encourage the people of the whole country towards a common goal to strive to provide the thinking power strong, the strong ideological ties to the big family of the Chinese nation's unity, prosperity. Colleges and universities undertake the task of training qualified builders and reliable successors of socialism, the more urgent need to adhere to the value system of college students with the socialist core armed, to enable them to become the core value system of socialism of learners, firm faith, positive disseminator and exemplary practitioner. How to strengthen the education of the socialist core value system in college students, improve the effectiveness of College Students' education of socialist core value system, value identification is an important link. The higher the value identity of the socialist core value system of college students, the more in thought and action is always keep consistent with the party. To realize the value identity of the socialist core value system, it is of great theoretical and practical significance.

\section{THE CONCEPT, VALUE ANALYSIS}

"Identity" is the concept of school self defense mechanism of psychoanalysis.Freud put the "identity" as is "self will process the real object in the environment and to meet the needs of my imagination corresponding. He also put this concept used to describe individuals to enhance their trend by accepting the role model behavior, style and features. (1) Also the scholar thinks, identity is an important concept in the social development, it has two different meanings of individual and society. "At the individual level, identity is confirmed to personal social angle or the identity of the reason, it is the lasting power of personal social behavior." "On the social level, identity is a social community members of certain beliefs and feelings of the common and share, it is the internal cohesion of the community" (2) The value identity, academic circles have different understanding, but to be sure, the value identity is a dynamic process, It can be used not only as a concept, the theory is to understand and use, but also can be used as a value practice and performance for the behavior and practice of selecting certain. Therefore, from a psychological and philosophical value theory, value identity refers to the value main body through the value cognition, value evaluation, choice of value activities always change its value structure, the concept of value, social value norms into their own value, and the value of the process behavior.

Any society, nation and country in the process of development and social practice activities in their own, will form a certain value concept system. In 2006 October, the sixteen session of the six plenary session of the "CPC Central Committee on the construction socialism harmonious society certain major issue decision", the first explicitly put forward the "building a socialist core value system" of this important proposition and strategic task. In 2007, President $\mathrm{Hu}$ Jintao in "6 • 25" emphasize in the speech, to the construction of the socialist core value system, the common thought foundation to consolidate the unity of the people. It consists of four aspects, namely the Marx principle guiding ideology, China socialism common ideal, with patriotism as the core of the national spirit and reform and innovation as the core spirit of the times, the socialist concept of honor and disgrace.

Two, college students agree with the conditions of the socialist core value system

\section{THE IDENTIFICATION OF CORE VALUE SYSTEM IS NOT COMPREHENSIVE.}

Values are hierarchical, constitute the main values divided into direct interest level and ideal level. The former is the basic component of values, the latter is the core values of the constitution; the former is the foundation, is to ensure that the existing material, the latter is the spiritual sublimation. The values of college students identity, first by the superficial level of interest identity, and then to the development of the ideal level of identity, the rational belief is just part of the identity, rather than the full range of identity. Similarly, the socialist core value system as a covering four aspects of contents, connotation is rich, vast extension system, college students on the value identity, 
come very naturally is a dynamic, continuous development of history, process, Understanding the majority of college students on the value system of socialist core Chinese is not comprehensive and profound, the identification of the socialist core value system is the certain aspects and the degree of identity.

As college students to take the patriotism as the core national spirit identity close to excellent level, of Marx's guiding ideology, Chinese socialism common ideal, the socialist concept of honor to identity to achieve the good level, but to reform and innovation as the core spirit of the times the recognition is not high, in the middle and lower level.(3)

\section{UNBALANCE VALUE IDENTITY OF SUBJECT.}

Unbalance value identity of subject, is that college students as a group, the degree of recognition of different individual students of the socialist core value system of different, Some students of the socialist core value system of the higher degree of recognition, some college students with the socialist core value system is low. For example, compared with the ordinary students, student Party member to the identification of the socialist core value system to the high degree of.

\section{THE IDENTITY OF CORE VALUE SYSTEM IN KNOWLEDGE, SENTIMENT, AN INCONSISTENCY.}

Group as the higher cultural level students, can realize deeply should stick to what, what to what, knock against, what.Because our party's long-term focus on the ideological and political theory education for the students, most of the students on the Chinese socialist core value system is the correct understanding, understanding and grasping. But along with the establishment and development of the socialist market economic system, and social thought in the West invasion and infiltration, Marx the guiding role of Marxism constantly challenged, people's concept of value diversification. At the same time, because of the pressure of the employment situation and social competition in terms of existence, in which part of the contemporary university students in the actual problem in real life, the common ideal of socialism education as empty, unrealistic preaching and not to be ignored, Thus in the minority college students in the socialist belief crisis and values distorted, so that students in the world outlook, outlook on life, values selection tend to be pragmatic, recognized the value of college students more remain in the level of cognition, cognition, affection and behavior identity is not consistent, in knowledge, feelings, for there the fracture.

\section{THREE, STRENGTHEN THE PROPOSAL OF THE SOCIALIST CORE VALUE VALUE IDENTITY OF COLLEGE STUDENTS}

1 , give full play to the ideological and political theory course teaching as the main channel and the campus cultural environment influence character by environment effects, in order to realize the college students' perceptions of identity of the socialist core value system.
Identity is the originator of the value, is the basis of emotional identity and behavior identity. Enhance the value identity of the socialist core value system, we should help students grasp and deep understanding of the socialist core value system of the basic content and the scientific connotation.

Ideological and political theory course is the main channel and the main position of Ideological and political education of college students, is the main way to instill theory for college students, but also enhance mainly rely on College Students' socialist core value system of value identity. To promote college students' identity of socialist core value system must give full play to the role of Ideological and political theory course. Ideological and political theory course itself has a strong political nature and ideology, its curriculum and comprehensive through the basic contents of the socialist core value system. So in the teaching to carry out "adhere to the principle of" integration of education and self education, the teachers' leading role and students. Should be based on the continuous reform and development changes in the theory and practice and innovation of teaching content, teaching method and teaching means. Study on the teaching law, unremittingly with the latest achievements of the Marx doctrine of college students armed China, guide students to grasp and understand the socialist core value system of the basic content and the spiritual essence, to really play a role of main channel of Ideological and political theory course in the ideological and political education of College students.

The second is the socialist core value system into the construction of campus culture. Colleges and universities should soft hardware construction through the campus, with a healthy, positive, innovative campus culture influence character by environment influence the thoughts and culture to the students. Guidance of political propaganda should give full play to the campus media and public opinion, the use of television, radio, newspaper, campus network, publicity windows and other campus media to maximize the value identity of socialist core value system education coverage.

\section{AFFECTIVE FACTORS IN ORDER TO ENRICH AND ATTRACTIVE, AROUSING STUDENTS' EMOTIONAL IDENTIFICATION OF THE SOCIALIST CORE VALUE SYSTEM.}

Emotion recognition is based on identity based on the socialist core value system, happy, grateful, confidence, enthusiasm and passion, positive affective factors fully mobilize and motivate the students, the socialist core value system to produce satisfaction, love and positive attitude. Contemporary college students' emotion, mood swings, but weak. University of the times, their social feelings have been improved rapidly, as their mission to the state of feeling, a sense of social responsibility, the collective sense of honor and the sense of moral life. Positive affective factors in the socialist core value system of national spirit, the spirit of the times, such as the concept of honor and disgrace, deeply to attract college students in emotion, and through the emotional role gradually influence and promote the formation of a correct understanding of the thinking framework and transform the world. In practice the empathy 
training, make use of the emotional experience, to eliminate the emotional resistance of students, stimulate their positive social emotion, to "move" and "reason" organically, so reasonable combination, complement each other, and for the realization of college students on the value identity of socialist core value system eventually provide good "catalyst" and fully guarantee.

\section{TO GUIDE STUDENTS ACTIVELY PRACTICE IN THE LIFE OF THE SOCIALIST CORE VALUE SYSTEM, TO ACHIEVE STUDENT BEHAVIOR IDENTITY OF THE SOCIALIST CORE VALUE SYSTEM.}

The value identity in essence is a kind of practice activity, is the practice of knowledge education and value education in education. The value identity not the socialist core value system of college students only stay in the idea and emotion, is more important in the socialist core value system into their own values and norms of behavior basis, to guide their practice, behavior identity formation. Therefore, the key of college students value identity of socialist core value system education of college students is the behavior identity.

The CPC Central Committee and State Council "on the further strengthening and improving ideological and political education opinion" clearly pointed out, social practice is an important link of Ideological and political education of college students, for the students to know the society, understanding of national conditions, increasing of ability, contributing to society, exercise capacity, and enhance their sense of social responsibility has irreplaceable function. Only university students actively participate in social practice, in practice to examine all, examine all, can make their own ideas to consciously from those who be inopportune or inappropriate ideas of liberation, liberated from the fetters of subjectivism and metaphysics, consciously use their socialist core value system armed, the subjective and the objective, the combination of theory and practice, to truly grasp the scientific connotation of socialist core value system, to achieve the real identity of the socialist core value system. Through the practice, on the one hand can make the students deepen the understanding of the socialist core value system of theoretical knowledge, so as to help students to establish correct world outlook, outlook on life and values; On the other hand, can make the students in the practice experience in the consciousness of identity of socialist core value system, and enhance the Marx's thought, Chinese socialism common ideal, with patriotism as the core of the national spirit and reform and innovation as the core spirit of the times and the socialist concept of honor and Disgrace is guiding the direction, the guidance of life consciousness. (4) Therefore, the value identity of socialist core value system in the process of education, we should actively take effective way of social practice, the gradual deepening of the socialist core value system of the understanding and recognition in the practice of College students. To the socialist core value system of cognition and emotional identity combine with daily life; at the same time to strengthen the coordination between the school and society, to promote life education, life education, make education more close to life, education can increase contact and perception; various kinds of practical activities should be targeted and maneuverability, can arouse the enthusiasm of students, and guide the student to carry on the summary and reflection through practice, the essence understanding of socialist core value system.

\section{INTRODUCTION OF AUTHORS}

Author introduction: Dai Caihong (1973--), female, Hainan Chengmai, master of Qiongtai Teachers College associate professor, Hainan, mainly engaged in the research of Ideological and political education, address: Hainan Hainan Qiongtai Teachers College.

\section{REFERENCES}

[1] Li Deshun. Study of value DICTIONARY [M]. Beijing: Renmin University of China press, 1995

[2] Wang Xinyan. The identity of value and the conflict of values in globalization [J]. Philosophical research, 2002

[3] Liang Ying. The factor of College Students' identification of the socialist core value system and its effect. (J). Learning and practice of.2009 (8)

[4] Long Yiping, Gao Jun. Adhere to the socialist core value system of Ideological and political education into [J]. Journal of Ideological and theoretical education, 2009 (6). 